\title{
LORD HORDER
}

Thomas Jeeves Horder was born on January 7, 1871 at Shaftesbury in Dorset, and died at Ashford Chase, near Petersfield on August 13, 1955, aged 84. The period of his medical life coincided with the era in which the general physician reached his fullest development: Horder was probably the most clinically acute member of that now rare group. The great flood of knowledge of the last generation has made it impossible for any man to be efficient in more than one aspect of medicine.

Horder was educated at Swindon High School and at St. Bartholomew's Hospital, where he won the entrance scholarship in 1891. He obtained the London M.B. with first class honours in 1897 and the M.R.C.P. and the London M.D. in 1899. He became House Physician to Samuel Gee and when Gee's Clinical Lectures were republished in 1906 he added many of Gee's aphorisms. Soon after this he started in consulting practice and was on the honorary staff of the Royal Northern Hospital, but it was not till 1912 that he was appointed to the staff of St. Bartholomew's. He became Senior Physician in 1933 and retired under the age limit in 1936.

He was knighted in 1918, made a baronet in 1923 and, ten years later, was raised to the peerage as Lord Horder of Ashford. He became G.C.V.O. in 1938.

He married in 1902, Geraldine, daughter of Arthur Doggett, and his wife died a year before him: they had one son and two daughters.

Horder's wide view of his profession never allowed him to become a cardiologist in the modern sense, and for this reason the passage of years slowly separated him from the cardiological world. He was, however, an original member of the Cardiac Club and attended the meetings regularly until he became an Extra-Ordinary member after his retirement. In 1922 he opened a discussion on infective endocarditis. This subject was the one in which he made his chief scientific contribution to cardiology. His work on the bacteriology of the disease, in which he was closely associated with Sir Frederick Andrews, was original and that of a pioneer. He was also interested in the ætiology of acute rheumatism, and by blood culture studies concluded that in this condition there was no streptococcal bacteriæmia.

In spite of his general approach his opinion in heart cases was sought to the end of his life. The reason was that his clinical judgement and his shrewd common sense so often revealed an essential fact hitherto hidden in a thicket of pseudo-scientific minutiæ. On one such occasion, in consultation with a cardiologist, after inspecting pathological reports and numerous cardiograms, he insisted on examining the lung bases although the patient was said to be too ill to move: a large posterior pleural effusion was discovered and removed, to the patient's lasting benefit.

The gift for collecting the facts that are reliable and have a direct bearing on diagnosis and prognosis, and of discarding those that are misleading or of less weight constitutes the sense of values inherent in a good clinician. Horder had this quality in its most valuable form. He was undisturbed by environment, occasion, or by previously expressed opinions. "If I am told a patient is suffering from this or that disease I do my best to disprove the statement," he once said to the writer. "If the diagnosis is wrong I have the best chance of finding this out. If it is right and I am forced to agree, the corroboration becomes valuable." With these qualities it is natural that he had a large consulting practice. He was medical adviser to many famous people, including three Kings and three Prime Ministers.

His was the scientific approach to medicine, to human activities, and to life as a whole. In other words he wished in all things for truth, and scorned falsity in all its forms. The opinion of the humblest house physician was considered by him strictly on its merits; the bombast of a pompous politician was treated in the same way.

He had an unusually wide range of interests and thought all these important because of his belief that medicine was one of the social sciences. Among these were the National Birth Control Association, the Eugenics Society, the National Smoke Abatement Society, and the Empire Rheumatism Council, and in many of these he took a leading part. He did not see why human beings should not be helped to become sensible in such matters as eugenics, cremation, birth-control, and noise abatement. In such matters he was not content to issue polemics: he entered the combatant lists, and fought hard himself. 


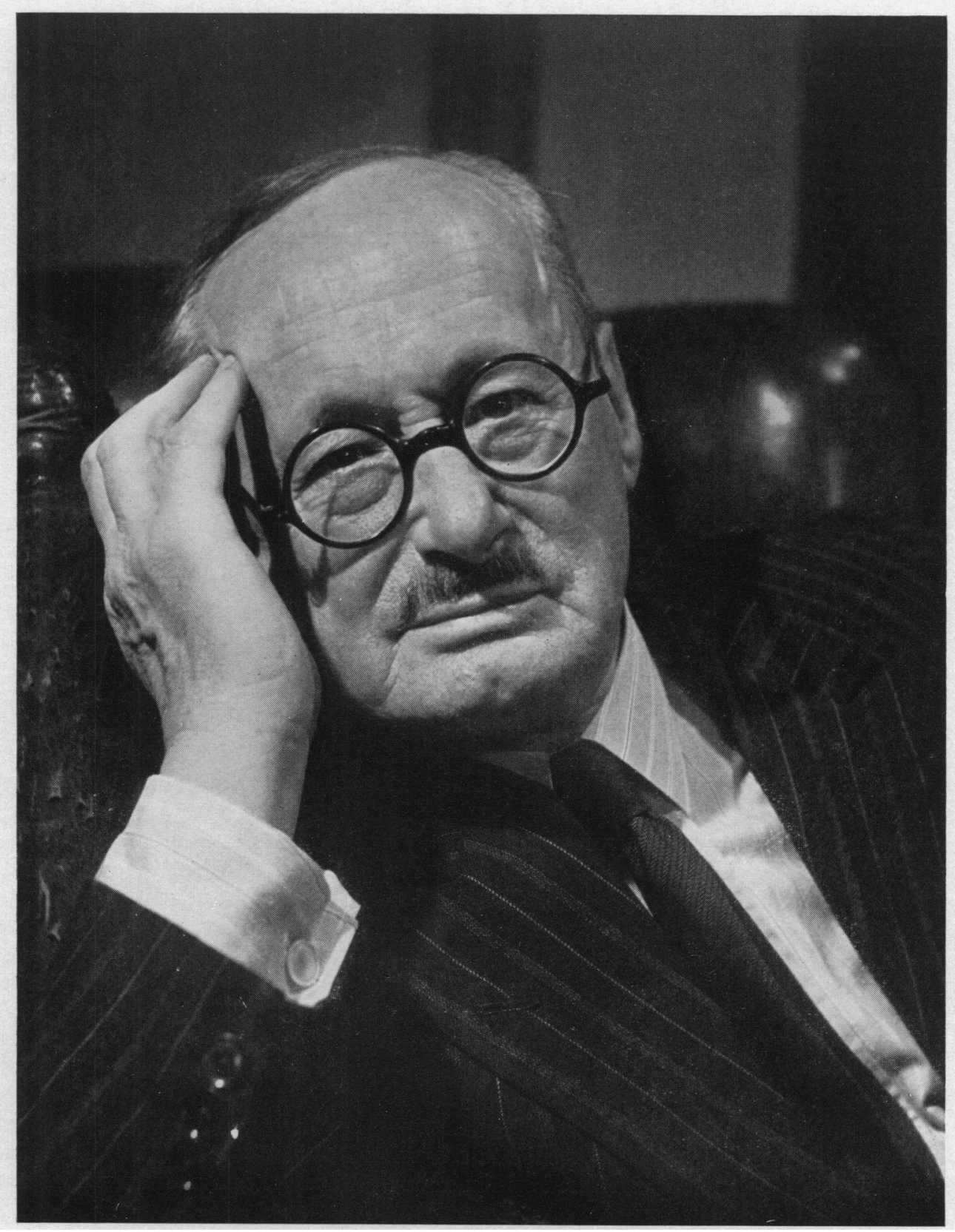

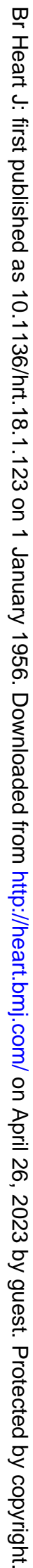


It was this quality of fighting for what he felt was right that caused him to found the Fellowship for Freedom in Medicine. He knew that medicine was basically an affair of two individuals-the doctor and the patient-and he saw plainly the dangers to medical practice threatened by so many aspects of a State Medical Service: the entry of the State, as a third person, into the relationship was a potential menace. He was never against a scheme in which finance, on a contributory basis, could be organized by the State, but he felt strongly that the medical side of any scheme should be organized and run by the medical profession.

He was all his life an individualist, and therefore in his later years became unfashionable, for it is now often forgotten that without the scientific advances of individualists this age of the common man could not exist. As an individual, although of relatively humble origin, he fought his way onto the staff of St. Bartholomew's, in the face of conservative medical and social orthodoxy at its most formidable. As an individual he made his way as a consulting physician, utilizing, as an aid to his native genius, the new weapons of clinical pathology which his seniors lacked. In his early days he did his own blood counts, sputum and urine examinations, and bacteriology. This approach to diagnosis took him quickly to the front rank of consulting clinical practice.

In the 1939-45 war he performed valuable services as chairman of a government committee that advised about the health measures needed for the large air raid shelters, such as the London tubes, and the absence of serious epidemics must owe something to his wisdom. He was also one of the advisers to Lord Woolton at the Ministry of Food. His wide interest in the social aspect of medicine is well shown in his volume of reminiscences, Fifty Years of Medicine, that was published in 1952.

It was not professional ability alone that made him a great man, for he had all the personal attributes of a fine character. He was honest, courageous, lovable, intensely interested in his fellow men, and generously self-sacrificing. In the 1918 influenza epidemic, when he was excessively busy, he came to the Evelina Hospital on several successive nights to visit the writer, previously his house-physician, who was seriously ill with the infection. "Bourne and I are friends" was his reply to someone commenting on his kindness. This action was typical of him.

His brisk actions and the penetrating timbre of his slightly harsh voice were vehicles of his wonderfully vivacious and active mind. His comments, in the face of pomposity or self-important stupidity, could be cutting. His outspokenness was symptomatic of his desire for truth for its own sake. His vitality shone brightly to the end of his life. Every weekend he drove himself down to Ashford Chase, where he worked in the unique and lovely garden he had made. He was greatly blessed in that his sparkling mind, his greatest gift, retained its lustre to his last hours. His was a great life.

GEOFFREY BOURNE 